UDC: 616.89-008.19-036.1-07:378.091.12.011.3

DOI: https://doi.org/10.24195/2414-4665-2017-7-11

Tetiana Bilous,

PhD (Candidate of Medical Sciences), associate professor, Department of Pediatrics and Children Infectious Diseases,

Maryana Dikal,

PhD (Candidate of Medical Sciences), associate professor, Department of Bioorganic and Biological Chemistry,

Liudmyla Kaniovska,

PhD (Candidate of Medical Sciences), associate professor, Department of Internal Medicine, Clinical Pharmacology and Occupational Diseases,

Bukovinian State Medical University,

2, Teatralna Square, Chernivtsi, Ukraine

\title{
RISK ASSESSMENT OF THE DEVELOPMENT AND SIGNS OF EMOTIONAL BURNOUT SYNDROME IN LECTURERS OF THEORETICAL AND PRACTICAL DEPARTMENTS OF MEDICAL UNIVERSITY
}

The paper aims to determine the presence and assess the intensity of the formation of emotional burnout syndrome in medical university lecturers. The experiment involved 48 lecturers who were divided into two groups. The first group of respondents included 27 representatives of theoretical departments (average age is 39.8, 87.5\% females, average working experience is 16.0 years), the second group included 21 lecturers from clinical departments (average age is 36.9, 81.0\% females, average pedagogical experience is 13.4 years, $p>0.05$ ). In order to examine the degree of emotional burnout syndrome the adapted Emotional Burnout Syndrome Inventory by V. Boyko was used. Experiencing psycho-traumatic circumstances was found to occur most frequently among the signs of "strain" phase ( $p<0.05)$, as well as anxiety and depression in the sphere of professional duties fulfillment $(p>0.05)$. The results obtained are indicative of a probable prevailing of the formation of all the symptoms of "resistance" phase among the representatives of the $1^{\text {st }}$ group as compared to the respondents of the $2^{\text {nd }}$ group. Emotional deficiency symptom of "exhaustion" phase was found to occur most frequently, and at the moment of carrying out the survey it was formed in $37.0 \%$ individuals of the $1^{\text {st }}$ group and $4.8 \%$ representatives of the $2^{\text {nd }}$ group $(p<0.05)$. At the same time, odds ratio of the formation of emotional deficiency symptom in the lecturers of theoretical departments in comparison with the staff members of clinical departments was 4.75 , relative risk -2.0 , absolute risk -0.37 , post-testing probability - 67.9\%. Personality rejection symptom (depersonalization) possessed rather high probability to be formed in the lecturers of theoretical departments: odds ratio was 4.2, relative risk -1.7 , likelihood ratio -2.9 , post-testing probability of events $-74.0 \%$. Emotional burnout syndrome among the lectures of the medical university is being formed in three phases. In the strain phase it is mostly characterized by excessive experience of psycho-traumatic circumstances, anxiety and depression; in resistance phase it is manifested in emotional thriftiness, and in exhaustion phase - by emotional deficiency and emotional rejection. The formation of emotional burnout syndrome is found to occur among the staff members of theoretical departments as compared to the representatives of clinical departments of the university.

Keywords: emotional burnout syndrome, medical university, lecturers, phases.

\section{Introduction}

Diagnostics and prevention of emotional or occupational burnout syndrome among medical practitioners and lecturers of medical higher educational establishments is an extremely relevant issue nowadays [1, p. 6]. Since the work of representatives of these professions is related to communication with students, patients and their relatives, colleagues, it results in the development of emotional burnout, fatigue and sensation of exhaustion followed by a number of professional stresses which are the main reason provoking the development of emotional burnout syndrome [12].

Emotional burnout syndrome was first examined among the employees of medical establishments at the Nevada University College of Care, where it was determined that this syndrome was a result of confrontation with reality when the human organism was exhausted in the struggle against circumstances that were difficult to change and followed by the formation of occupational autism [7, p. 9]. Technically professional duties are performed by such an employee completely, although emotional contribution transforming the task into a creative form is not available.

C. Maslach, Professor of Psychology at California University provided a considerable supplement to understanding emotional burnout syndrome. He indicated that this syndrome touched upon not only emotional and mental exhaustion occurring at the ground of chronic stress caused by interpersonal communication, but assumed physical exhaustion available resulting in the development of negative self-esteem, negative attitude to work, loss of understanding and sympathy to surrounding peo- 
ple [8, p. 15].

Nowadays some authors associate the formation of emotional burnout syndrome with chronic stress at work and high organizational requirements that in the course of time result in emotional exhaustion, increased anxiety and depression $[16,18,20]$. At the same time emotional burnout syndrome is considered to be the main cause of a preterm retirement of high school teachers. Researchers admit that this syndrome occurs more often in women, divorced teachers and educators working part-time [13, 14].

A generalizing pattern of emotional burnout syndrome developed by $\mathrm{C}$. Maslach assumes the presence of three groups of signs: emotional exhaustion, depersonalization and reduction of personal achievements. Today Maslach Burnout Inventory (MBI) is one of the most popular questionnaires used to determine presence and expressiveness of emotional burnout syndrome [11]. There are also other popular inventories, for example, Copenhagen Burnout Inventory - CBI, Oldenburg Burnout Inventory - OLBI, etc. [17, 19].

The completest classification of signs forming emotional burnout syndrome consists of 132 symptoms united into the five main groups $[2,4]$ :

- affective ones manifested in depressive, pessimistic and gloomy mood, anxiety, uncertain fear, nervousness, and feeling guilty. When communicating a professional manifests the signs of irritability, overreacts to environmental changes, and becomes emotionally hardhearted. Attacks of irritability and anger are possible, sensations of discomfort and discontent with the results of professional activity may also occur.

- cognitive ones characterized by disorders of thinking processes, memory disorders, reduced attention focusing. Cynical and inhumane perception and attitude to the surroundings are formed at the level of interpersonal contacts. In communication with colleagues and managers such a person manifests excessively critical attitude to the surroundings that can be transformed into aggressive behavior against colleagues, unwillingness to cooperate, and detachment.

- physical symptoms manifested in a sensation of general fatigue, cephalgia and myalgia, dizziness, sleep disorders. The development of psychosomatic disorders, most often of the gastrointestinal tract and cardio-vascular system, are also characteristic features.

- behavioural disorders characterized by excessive anxiety manifested in restlessness, hyperactivity and inability to focus on working issues. The behavior of such staff members differs by impulsivity, straightness, and at the same time hesitation, inclination to postpone things till later times. Constant tension and stress at work result in increased consume of coffee, alcohol, smoking, drugs intake promoting addiction and reducing the volume of internal energy resources essential to withstand stress. Aggressive behavior is observed in communication provoking conflicts both at work and in family life. Although, simultaneously a tendency to social isolation, avoidance of contacts with other people develops, professional activity effectiveness decreases, indifference to professional duties appears, sometimes violation of labour discipline occurs.

- motivational, manifested in gradual loss of interest to the surroundings; such people become indifferent to the needs of other people, unwilling to help in solution of urgent problems, they are not initiative at work.

Considering variability of signs of this syndrome it should be noted that professional burnout is of rather complicated structure, which means that many symptoms are manifested in different ways in specialists taking into account certain circumstances of their professional and personal behavior [5, p. 10].

The paper aims to examine the presence and intensity of emotional burnout syndrome in medical university lecturers.

\section{Research Methods}

The experiment involved 48 lecturers of Higher State Educational Establishment of Ukraine "Bukovinian State Medical University". The first group of respondents included 27 representatives of theoretical departments (average age is $39.8 ; 87.5 \%$ females, average working experience is 16.0 years), the second group included 21 lecturers from clinical departments (average age is $36.9 ; 81.0 \%$ females, average pedagogical experience is 13.4 years, $\mathrm{p}>0.05$ ).

In order to examine the degree of emotional burnout the adapted Emotional Burnout Syndrome Inventory by V. Boyko [3] was applied, enabling to diagnose not only the symptoms of emotional burnout and the degree of its formation and developmental phase, but to check the presence of psychosomatic and psycho-vegetative disorders. The questionnaire includes 84 statements. The results were interpreted according to three phases including four symptoms each. The total score was calculated for each out of 12 signs as well as the total score for every out of 3 stages of emotional burnout formation. In case the total sum of scores is less than 9 the symptoms of emotional burnout syndrome are considered to be unformed, if the total sum of scores is 10-15 the symptoms are being formed, and if the total sum of scores is 16 and more - the symptoms are considered to be formed. The total sum of the scores for the stage/phase less than 36 was considered to be unformed, in case of 37-60 - the phase was considered to be in the process of its formation, and if the total sum was more than 60 it was considered to be the formed phase of emotional burnout. The results obtained were analyzed by means of Statistica 7.0 StatSoft Inc. with the use parametric and non-parametric methods of calculation.

\section{Research Results and their Discussion}

It should be noted that among the lecturers of theoretical departments involved in the experiment about $50.5 \%$ of them did not have their own classroom as compared to the representatives of clinical departments $(33.3 \%)$. They also experienced certain inconveniences sharing working facilities with other colleagues $(75.0 \%$ 
against $33.3 \%, \mathrm{p}<0,05)$. At the same time, the majority of the university lecturers participating in the experiment admit good relations with the university authority $-75 \%$ of the $1^{\text {st }}$ group and $71.4 \%$ representatives of the $2^{\text {nd }}$ group $(\mathrm{p}>0,05)$.

The results of the assessment of the presence and expression of the formation of "strain" phase signs are presented in Table 1. Experience of psycho-traumatic circumstances was found to occur most frequently among the signs of "strain" phase (the sign was formed in $44.4 \%$ individuals of the $1^{\text {st }}$ group and $19.0 \%$ representatives of the $2^{\text {nd }}$ group, $\mathrm{p}<0.05$ ), as well as anxiety and depression in the sphere of professional duties fulfillment (the sign was formed in $25.9 \%$ cases of the $1^{\text {st }}$ group and $14.3 \%$ of the $2^{\text {nd }}$ group, $\left.p>0,05\right)$. At the same time, "strain" phase was formed in 5 individuals of the $2^{\text {nd }}$ group $(23,8 \%)$ and it was not formed in any lecturers of the $2^{\text {nd }}$ group, although among representatives of theoretical departments this phase was being formed in 11 lecturers $(40.7 \%$, $\mathrm{p}>0.05)$ and had been formed in 6 individuals $(22.2 \%, \mathrm{p}$ I:II $<0.05)$.

The average score by the signs of "strain" phase in the groups of comparison $(M \pm m)$

\begin{tabular}{|l|l|l|c|}
\hline \multicolumn{1}{|c|}{ Symptoms of 1 "strain" phase } & \multicolumn{1}{c|}{ I group } & II group & p \\
\hline Experiencing psycho-traumatic circumstances & $14.8 \pm 1.92$ & $9.7 \pm 1.67$ & $<0.05$ \\
\hline Dissatisfaction with oneself & $6.8 \pm 0.79$ & $6.9 \pm 1.09$ & $>0.05$ \\
\hline Sensation of being cornered & $6.6 \pm 1.44$ & $5.5 \pm 0.93$ & $>0.05$ \\
\hline Anxiety and depression & $12.8 \pm 1.62$ & $9.4 \pm 1.81$ & $>0.05$ \\
\hline Total sum for 1 phase & $40.6 \pm 4.61$ & $23.9 \pm 3.36$ & $<0.05$ \\
\hline
\end{tabular}

It should be noted that an absolute risk of "strain" phase formation of emotional burnout syndrome in the lecturers of theoretical departments as compared to the staff members of clinical departments was 0.57 , relative risk was assessed to be 3.9 (95\% CI: 1,75-8,54), odds ratio was 13.6 (95\% CI: $3.09-59.83)$ with $27.3 \%$ increase of post-testing probability.

The analysis of the intensity of emotional burnout symptoms formation in "resistance" phase is presented in Table 2.

Table 2.

The average score by the signs of "resistance" phase in the groups of comparison (M士m)

\begin{tabular}{|l|l|l|l|}
\hline \multicolumn{1}{|c|}{ Symptoms of 2 "resistance" phase } & \multicolumn{1}{c|}{ I group } & II group & p \\
\hline Inadequate emotional selective response & $18.2 \pm 0.89$ & $10.4 \pm 1.48$ & $<0.05$ \\
\hline Emotional-moral disorientation & $13.1 \pm 1.28$ & $6.6 \pm 1.01$ & $<0.05$ \\
\hline Widening of emotional thriftiness sphere & $24.1 \pm 3.04$ & $15.8 \pm 2.52$ & $<0.05$ \\
\hline Reduction of professional duties & $18.1 \pm 1.64$ & $11.4 \pm 1.45$ & $<0.05$ \\
\hline Total sum for 2 phase & $73.6 \pm 4.89$ & $38.5 \pm 3.72$ & $<0.05$ \\
\hline
\end{tabular}

The results obtained are indicative of a probable prevailing of the formation of all the symptoms of "resistance" phase among the representatives of the $1^{\text {st }}$ group as compared to the respondents of the $2^{\text {nd }}$ group. Thus, the symptom of inadequate emotional selective respond was found in all the individuals of the $1^{\text {st }}$ group involved in the experiment - it was being formed in $29.6 \%$ and already formed in $70.3 \%$ cases, which is considerably higher than that in the $2^{\text {nd }}$ group (the symptom was being formed in $47.6 \%$ and already formed in $4.8 \%$ cases, $\mathrm{p}<0.05$ ).

A completely formed emotional-moral disorientation symptom occurred in $40.7 \%$ lecturers of the $1^{\text {st }}$ group and $4.8 \%$ in the group of comparison $(p<0.01$ ), the symptom of emotional thriftiness sphere expanding $-70.4 \%$ and $47.6 \%$ respectively ( $\mathrm{p}>0.05)$. A formed symptom of professional duties reduction indicative of the desire to spend as little time as possible to perform professional duties was found in $55.6 \%$ representatives of the $1^{\text {st }}$ group and $28.6 \%$ lecturers of clinical departments $(\mathrm{p}<0.05)$.

In the process of formation of "resistance" phase of emotional burnout syndrome among the representatives of theoretical departments inadequate emotional selective respond symptom had the highest risk (Table 3), when uncontrolled mood affected the relations with surrounding people and together with professional duties reduction, manifested in reduced intensity of educational activity and desire to spend as little time as possible to perform professional duties.

Table 4 presents the results of the experiment with the scores of "exhaustion" phase symptoms. Emotional deficiency symptom was found to occur most frequently, and at the moment of holding the survey it was formed in $37.0 \%$ individuals of the $1^{\text {st }}$ group and $4.8 \%$ representatives of the $2^{\text {nd }}$ group $(p<0,05)$. At the same time, odds ratio of emotional deficiency symptom formation in the lecturers of theoretical departments in comparison with the staff members of clinical departments was 4.75 (95\% CI: 1.39-16.21), relative risk - 2.0, absolute risk - 0.37, post-testing probability $67.9 \%$. Personality rejection symptom (depersonalization) possessed rather high probability of formation in the lecturers of theoretical departments: odds ratio is 4.2 (95\% CI: $0.97-17.47$ ), relative risk is 1.7 , likelihood ratio is 2.9 , post-testing probability of events is $74.0 \%$. 
Table 3 .

Risk indices of formation of certain symptoms of "resistance" phase of emotional burnout syndrome among the lecturers of theoretical departments

\begin{tabular}{|l|c|c|c|c|}
\hline \multicolumn{1}{|c|}{ Index } & Odds ratio & Absolute risk & Relative risk & $\begin{array}{c}\text { Post-testing } \\
\text { probability, \% }\end{array}$ \\
\hline $\begin{array}{l}\text { Inadequate emotional selective respond symp- } \\
\text { tom }\end{array}$ & $\begin{array}{c}45.5 \\
(0.46-129.49)\end{array}$ & 7.76 & 0.70 & 65.54 \\
\hline Emotional-moral disorientation symptom & $\begin{array}{c}10.1 \\
(2.57-39.60)\end{array}$ & 2.58 & 0.51 & 78.70 \\
\hline $\begin{array}{l}\text { Widening of emotional thriftiness sphere } \\
\text { symptom }\end{array}$ & $\begin{array}{c}2.2 \\
(0.61-7.63)\end{array}$ & 1.44 & 0.19 & 55.68 \\
\hline Professional duties reduction symptom & $\begin{array}{c}5.2 \\
(1.34-20.45)\end{array}$ & 2.37 & 0.39 & 61.92 \\
\hline Formation of "resistance" phase & $\begin{array}{c}11.4 \\
(2.13-60.71)\end{array}$ & 4.17 & 0.53 & 63.87 \\
\hline
\end{tabular}

Table 4.

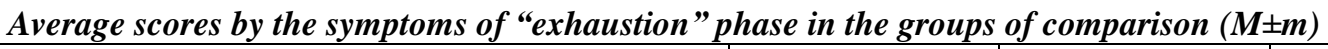

\begin{tabular}{|l|l|l|c|}
\hline \multicolumn{1}{|c|}{ Symptoms of 3 “exhaustion" phase } & \multicolumn{1}{c|}{ I group } & II group & p \\
\hline Emotional deficiency & $13.4 \pm 1.34$ & $8.7 \pm 1.32$ & $<0.05$ \\
\hline Emotional rejection & $10.8 \pm 0.87$ & $7.8 \pm 1.39$ & $>0.05$ \\
\hline Personality rejection (depersonalization) & $7.9 \pm 1.70$ & $7.4 \pm 0.80$ & $>0.05$ \\
\hline Psychosomatic and psycho-vegetative disorders & $8.8 \pm 1.85$ & $7.1 \pm 1.07$ & $>0.05$ \\
\hline Total score for 3 phase & $40.9 \pm 4.24$ & $24.6 \pm 3.04$ & $<0.05$ \\
\hline
\end{tabular}

In general, it should be noted that at the moment of carrying out the experiment the process of formation of one of the phases or several phases of emotional burnout syndrome occurred among the lecturers of theoretical departments $(63.0 \%)$, and in $74.1 \%$ cases they were already formed. Among the representatives of clinical departments at the same period of time the phases of emotional burnout syndrome were being formed in $61.9 \%$ cases, and one phase was already formed in $14.3 \%$ respondents $(\mathrm{p}<0.05)$ of the experiment.

\section{Conclusions}

1. Emotional burnout syndrome in the lectures of the medical university is formed in three phases; it is mostly characterized in the strain phase by excessive

\section{REFERENCES}

1. Berezovska, L.I. (2015). Profesiine vyhoriannia pratsivnykiv suchasnykh osvitnikh orhanizatsii [Professional burnout of workers of modern educational organizations]. Naukovyi visnyk Mukachivskoho derzhavnoho universytetu -Scientific Bulletin of the Mukachevo State University, 1(1), 130-135 [in Ukrainian].

2. Besuchuk-Venherska, N.V. (2015). Profilaktyka syndromu profesiinoho vyhorannia u pedahohiv. Metod. posibnyk [Prevention of professional burnout syndrome among teachers. Methodical manual]. Vinnitsa: MMK. Retrieved from: https://dorobok.edu.vn.ua/ article/view/1257. [in Ukrainian].

3. Boyko, V. V. (2004). Energiya emotsiy [The energy of emotions]. St. Petersburg: Peter [in Russian].

4. Grinberg, J. (2002). Stress Management Transl [Upravlenye stressom]. From English by L. Gitelman, M. experience of psycho-traumatic circumstances, anxiety and depression; in resistance phase it is manifested in emotional thriftiness sphere, and in exhaustion phase - in emotional deficiency and emotional rejection.

2. The formation of emotional burnout syndrome is found to occur among the staff members of theoretical departments as compared to the representatives of clinical departments of the university.

3. Inadequate emotional selective respond symptom in the "resistance" phase possesses the highest risk of development among the lecturers of theoretical departments which is indicative of the necessity for direct prevention and appropriate psychological training focused on this very aspect of emotional burnout.

Potapova]. St. Petersburg: Peter [in Russian].

5. Zelinskaya, Ya. (2009). Osoblyvosti psykhichnoho vyhorannia $\mathrm{v}$ aspekti profesiinoho stresu [Features of mental burnout in the aspect of professional stress]. Sotsialna psykholohiia - Social Psychology, 6 (38), 127-135 [in Ukrainian].

6. Karamushka, L. M. (2004). Psykholohiia osvitnoho menedzhmentu: navch. Posibnyk [Psychology of Educational Management: Teach. Manual]. Kyiv: Lybid [in Ukrainian].

7. Nazarenko, I. P. (2011). Syndrom emotsiinoho vyhorannia sered medychnykh pratsivnykiv psykhiatrychnoi sfery [The syndrome of emotional burnout among medical workers in the psychiatric sphere]. Novosti meditsiny $i$ farmatsii. Psikhiatriya - Medicine and Pharmacy News: Psychiatry. (Vol. 383). Retrieved from: http://www.mifua.com/archive/article/20574. 
8. Lukyanov, V. V., Vodopianov, N. E., Orel, V. E., et. al. (2008). Sovremennye problemy issledovaniya sindroma vygoraniya u spetsialistov kommunikativnykh professiy: koll. monohrafiya [Modern challenges of the study of burnout syndrome at the specialists of communicative professions: collective monograph]. Kursk [in Russian].

9. Sudakova, O. S. (2012). Spetsyfika rozvytku syndromu emotsiinoho vyhorannia u likariv-onkolohiv [Specificity of the development of a syndrome of emotional burnout in oncologists]. Med. Psykholohiia-Med. Psychology, 4, 92-96 [in Ukrainian].

10. Chepileva, N. O. (2010). Psykholohichni osoblyvosti emotsiinoho vyhorannia vykladachiv vyshchykh navchalnykh zakladiv [Psychological features of emotional burnout of teachers of higher educational establishments]. Extended abstract of candidate's thesis. Odessa [in Ukrainian].

11. Kalliath, T. J., O'Driscoll, M. P., Gillespie, D. F. \& Bluedorn, A. C. (2000). A test of the Maslach Burnout Inventory in three samples of healthcare professionals. An International Journal of Work, Health \& Organisations, Vol. 14, Iss.1, 35-50. doi:10.1080/026783700417212 [in English].

12. Brotheridge C.M., Grandey A.A. (2002). Emotional Labor and Burnout: Comparing Two Perspectives of "People Work". Journal of Vocational Behavior, Vol. 60, Iss. 1, 17-39. doi:10.1006/jvbe.2001.1815 [in English].

13. Chang, M.L. (2009) An Appraisal Perspective of Teacher Burnout: Examining the Emotional Work of Teachers. Educational Psychology Review, Vol. 21, 193 218. doi:10.1007/s10648-009-9106-y [in English].

14. Bauer J., Stamm A., Virnich K. (2006). Correlation

\section{ЛІТЕРАТУРА}

1. Березовська Л.І. Професійне вигоряння працівників сучасних освітніх організацій / Л.І. Березовська // Науковий вісник Мукачівського державного університету. - 2015. - №1 (1). - С. 130-135.

2. Бещук-Венгерська Н.В. Профілактика синдрому професійного вигорання у педагогів. Метод. посібник / Бещук-Венгерська Н.В. - Вінниця: ММК, 2015. - 39 c.

3. Бойко В.В. Энергия эмоций. - СПб.: Питер, 2004. -474 c

4. Гринберг Дж. Управление стрессом / Дж. Гринберг ; [пер. с англ. Л. Гительман, М. Потапова]. СПб. : Питер, 2002. - 496 с.

5. Зелінська Я. Особливості психічного вигорання в аспекті професійного стресу / Я. Зеленіська // Соціальна психологія. - 2009. - №6 (38). - С. 127-135.

6. Карамушка Л.М. Психологія освітнього менеджменту : навч. посібник. / Л.М. Карамушка - К.: Либідь, 2004. - 424 с.

7. Назаренко І.П. Синдром емоційного вигорання серед медичних працівників психіатричної сфери / І.П. Назаренко // Новости медицины и фармации. $\begin{array}{lllll}\text { Психиатрия. } & - & 2011 . & - & \text { №383. }\end{array}$ http://www.mifua.com/archive/article/20574. between burnout syndrome and psychological and psychosomatic symptoms among teachers. International Archives of Occupational and Environmental Health, (Vol. 79), 3, 199204. doi:10.1007/s00420-005-0050-y [in English].

15. Gold, Y., Roth, R. (2005). Teachers Managing Stress and Preventing Burnout: the Professional Health Solution. Taylor \& Francis e-Library [in English].

16. Hakanena Jari J., Bakkerb Arnold B., Schaufelic Wilmar B. (2006). Burnout and work engagement among teachers. Journal of School Psychology, (Vol. 43), 6, 495513. https://doi.org/10.1016/j.jsp.2005.11.001 [in English].

17. Halbesleben, J.R.B., Demerouti, E. (2005). The construct validity of an alternative measure of burnout: Investigating the English translation of the Oldenburg Burnout Inventory. An International Journal of Work, Health \& Organisations, (Vol. 19), 3, 208-220. doi:10.1080/02678370500340728 [in English].

18. Schaufeli, W.B., Bakker, A.B., Hoogduin, K., Schaap, C. \& Kladler, Atilla (2001). On the clinical validity of the maslach burnout inventory and the burnout measure. Psychology \& Health, (Vol. 16), 5, 565-582. doi:10.1080/08870440108405527 [in English].

19. Kristensen, T.S., Borritz, M., Villadsen, E. \& Christensen, K.B. (2005). The Copenhagen Burnout Inventory: A new tool for the assessment of burnout. An International Journal of Work, Health \& Organisations, (Vol. 19), 3, 192-207. doi:10.1080/02678370500297720 [in English].

20. Weber A., Jaekel-Reinhard A. (2000). Burnout Syndrome: A Disease of Modern Societies? Occup. Med. (Lond), 50 (7), 512-517. doi:10.1093/occmed/50.7.512 [in English].

8. Современные проблемы исследования синдрома выгорания у специалистов коммуникативных профессий: колл. монография / под ред. В.В. Лукьянова, Н.Е. Водопьяновой, В.Е. Орла, С.А. Подсадного, Л.Н. Юрьевой, С.А. Игумнова ; Курск. гос. ун-т. Курск, 2008. - 336 с.

9. Судакова О.С. Специфіка розвитку синдрому емоційного вигорання у лікарів-онкологів / О.С. Судакова // Мед. психологія. - 2012. - № 4. - С. 92-96.

10. Чепелєва Н.О. Психологічні особливості емоційного вигорання викладачів вищих навчальних закладів : автореф. дис. на здобуття наук. ступеня канд. психол. наук : спец. 19.00.01 «загальна психологія, історія психології» / Н.О. Чепелєва. - Одеса, 2010. - 20 с.

11. A test of the Maslach Burnout Inventory in three samples of healthcare professionals / T.J. Kalliath, M.P. O'Driscoll, D.F. Gillespie [et al.] // An International Journal of Work, Health \& Organisations. - 2000. - Vol. 14, Iss. 1. - P. 35-50. doi:10.1080/026783700417212.

12. Brotheridge C.M. Emotional Labor and Burnout: Comparing Two Perspectives of "People Work" / C.M. Brotheridge, A.A. Grandey // Journal of Vocational Behavior. - 2002. - Vol. 60, Iss. 1. - P. 17-39. doi:10.1006/jvbe.2001.1815. 
13. Chang M.L. An Appraisal Perspective of Teacher Burnout: Examining the Emotional Work of Teachers / M.L. Chang // Educational Psychology Review. -2009. Vol. 21. - P. 193-218. doi:10.1007/s10648-009-9106-y.

14. Correlation between burnout syndrome and psychological and psychosomatic symptoms among teachers / J. Bauer, A. Stamm, K. Virnich [et al.] // International Archives of Occupational and Environmental Health. - 2006. - Vol. 79. - P. 199-204. doi:10.1007/s00420-005-0050-y.

15. Gold Y., Roth R. Teachers Managing Stress and Preventing Burnout: the Professional Health Solution / Y. Gold, R. Roth. - Taylor \& Francis e-Library, 2005. - p. 215.

16. Hakanena J.J. Burnout and work engagement among teachers / J.J. Hakanena, A.B. Bakkerb, W.B. Schaufelic // Journal of School Psychology. - 2006. - Vol. 43, Iss. 6. - P. 495-513. doi:10.1016/j.jsp.2005.11.001. alternative measure of burnout: Investigating the English
17. Halbesleben J.R.B. The construct validity of an

translation of the Oldenburg Burnout Inventory / J.R.B. Halbesleben, E. Demerouti // An International Journal of Work, Health \& Organisations. - 2005. - Vol. 19. - P. 208-220. doi: 10.1080/02678370500340728.

18 . On the clinical validity of the maslach burnout inventory and the burnout measure / W.B. Schaufeli, A.B. Bakker, K. Hoogduin [et al.] // Psychology \& Health. 2001. - Vol. 16, Iss. 5. - P. 565-582. doi:10.1080/08870440108405527.

19. The Copenhagen Burnout Inventory: A new tool for the assessment of burnout / T.S. Kristensen, M. Borritz, E. Villadsen [et al.] // An International Journal of Work, Health \& Organisations - 2005. - Vol. 19, Iss. 3. P. 192-207. doi:10.1080/02678370500297720.

20. Weber A. Burnout Syndrome: A Disease of Modern Societies? / A. Weber, A. Jaekel-Reinhard // Occup. Med. (Lond). - 2000. - Vol. 50 (7). - P. 512-517. doi:10.1093/occmed/50.7.512.

Тетяна Михайлівна Білоус, кандидат медичних наук, доиент кафедри педіатрії та дитячих інфекиійних хвороб,

Мар'яна Вікторівна Дікал, кандидат медичних наук, доиент кафедри біоорганічної і біологічної хімії та клінічної біохімії,

Людмила Володимирівна Каньовська, кандидат медичних наук, дочент кафедри внутрімньої медицини, клінічної фармакологї̈ та професійних хвороб, Буковинський державний медичний університет, Театральна площча, 2, м. Чернівці, Украӥна

\section{ДОСЛІДЖЕННЯ РИЗИКУ РОЗВИТКУ ТА ПРОЯВУ СИНДРОМУ ЕМОЦІЙНОГО ВИГОРАННЯ} У ВИКЛАДАЧІВ ТЕОРЕТИЧНИХ І ПРАКТИЧНИХ КАФЕДР МЕДИЧНОГО УНІВЕРСИТЕТУ

Метою роботи є визначення наявності та інтенсивності формування синдрому емоційного вигорання у викладачів медичного університету. Було проведено анкетування викладачів, яких було поділено на дві групи. Першу групу респондентів сформували 27 представників теоретичних кафедр (середній вік - 39,8 років, 87,5\% осіб жіночої статі, середній стаж роботи - 16,0 років), другу групу порівняння - 21 викладач із клінічних кафедр (середній вік $36,9$ років, $81,0 \%$ осіб жіночої статі, середній педагогічний стаж - 13,4 років, p $>0,05)$. Для проведення дослідження було використано методика діагностики рівня емоційного вигорання за В. В. Бойко. Виявлено, що найчастіше серед симптомів фази «напруження» траплялися переживання психотравмуючих обставин (p<0,05), а також тривога $\mathrm{i}$ депресія у сфері виконання професійних обов'язків (р>0,05). Виявлено й вірогідне переважання формування усіх симптомів фази «резистенції» у представників I групи порівняно з респондентами II групи. Найчастіше із симптомів фази «виснаження» траплявся симптом емоційного дефіциту, причому на момент анкетування він сформувався у $37,0 \%$ осіб I групи та у 4,8\% представників II групи ( $<0,05)$. При цьому відношення шансів формування симптому емоційного дефіциту у викладачів теоретичних кафедр порівняно зі співробітниками кафедр клінічного профілю сягало 4,75 , відносний ризик - 2,0, абсолютний ризик - 0,37, посттестова ймовірність - 67,9\%. Водночас симптом особистісної відстороненості (деперсоналізації) мав досить високу ймовірність формування у педагогічного колективу теоретичних кафедр: відношення шансів - 4,2, відносний ризик - 1,7, відношення правдоподібності - 2,9, посттестова ймовірність реалізації події - 74,0\%. Синдром емоційного вигорання викладачів медичного університету формується у три фази, з яких у фазі напруження він характеризується переважно надмірним переживанням психотравмуючих обставин, тривогою та депресією, у фазі резистенції проявляється економією емоційної сфери, а у фазі виснаження - емоційним дефіцитом та емоційною відстороненістю. Виявлено, що формування синдрому емоційного вигорання частіше трапляється у педагогічного колективу теоретичних кафедр.

Ключові слова: синдром емоційного вигорання, медичний університет, викладачі, фази.

Submitted on June, 6, 2017 